\title{
東京医科歯科大学医学部附属病院 リハビリテーション部
}

酒井朋子先生

\section{超早期リハビリテーション医療で 国内最短日数の回復をめざす}

都心の中心部，文京区御茶ノ水にある東京医科 歯科大学医学部附属病院は, JR, 地下鉄などの駅 も近く，交通アクセスがよいために，年間延べ 80 万人を超える患者さんが集まります。

「リハビリテーション治療は, 治療が一段落した ら開始というのではなく, 外傷, 手術, 急性期疾患 の治療開始と同時に早期から始めることが，良好 な機能回復へつながります．当院は専門性の高い 整形外科手術や，重篤な疾患・難治疾患に対する 積極的な治療が行われていますが，それぞれの病 態に合わせて, 超急性期からリハビリテーション治 療を導入し，早期回復を図っています」と説明する 酒井朋子リハビリテーション部部長. 先生ご自身 は, 股関節外科, 特に脳性麻痺や重症心身障害に 対する小児リハビリテーション医療がご専門です.

「当院の最大の特徴は,『救急車を断らない』『救 急車で来院した患者さんはすべて救急科が対応す る』をモットーに，国立大学救命救急センターとし てトップクラスの救急車受け入れを達成し続けて いることです。これ以外に，他院からの紹介患者 に対するハイレベルな外科手術なども多数行われ ており，2017 年は年間 8,933 件の手術を行ってい ます。このような病院の特色に対応して, リハビリ テーション部では, 外科手術後の早期離床, 早期

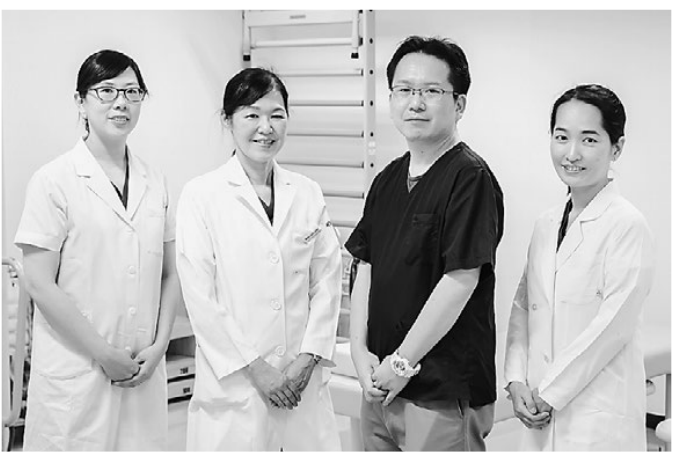

リハビリテーション科医師の集合写真

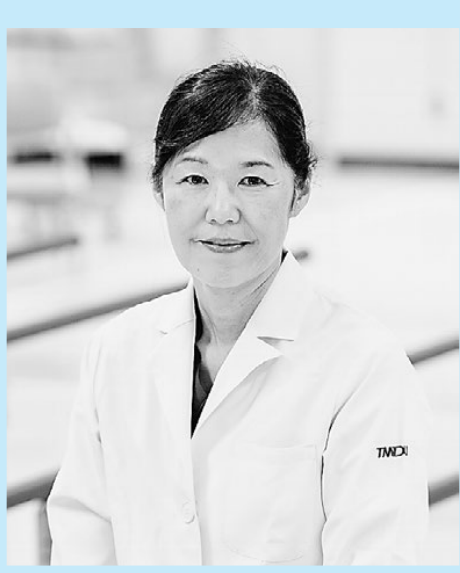

酒井朋子先生

東京医科歯科大学医学部附属病院 リハビリテーション部

病床数 : 315 床（回復期リハビリテーション病棟 40 床を含む), スタッフ構成 : 医師 4 名, 理学療 法士 19 名, 作業療法士 6 名, 言語聴覚士 4 名 于113-8510 東京都文京区湯島 1-5-45

退院を促すためのリハビリテーション治療はもちろ ん, 急性期脳卒中に対する早期リハビリテーション 治療や, ICUに扔ける超早期リハビリテーション医 療の中でも, early mobilizationに力を注いで, 常 に国内で最短日数での回復が得られるように工夫 しています」と話す先生.

\section{毎朝 8 時からの多職種回診が奏功}

超急性期から患者さんの病状に合わせた適切な 医療を行うために, 医師, 看護師, 理学療法士, 管 理栄養士など，さまざまな医療スタッフが毎朝 8 時に ICU に集合し，患者のベッドサイドで多職種 回診を行っているそうです.

「リハビリテーション部も毎日担当者を決めて 参加しています．患者さんの状態を目の前でみな がら，前日よりも回復したところや障害が残ってい る部分などを検証し，多職種のスタッフによる専門 的な視点で意見を交換することで，その日その日 


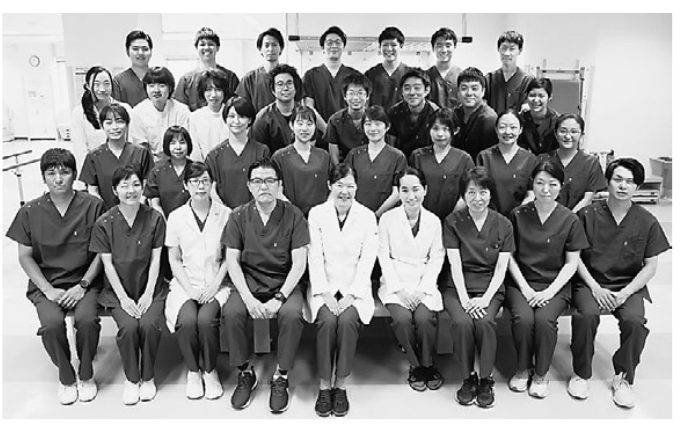

リハビリテーション部全スタッフ集合写真

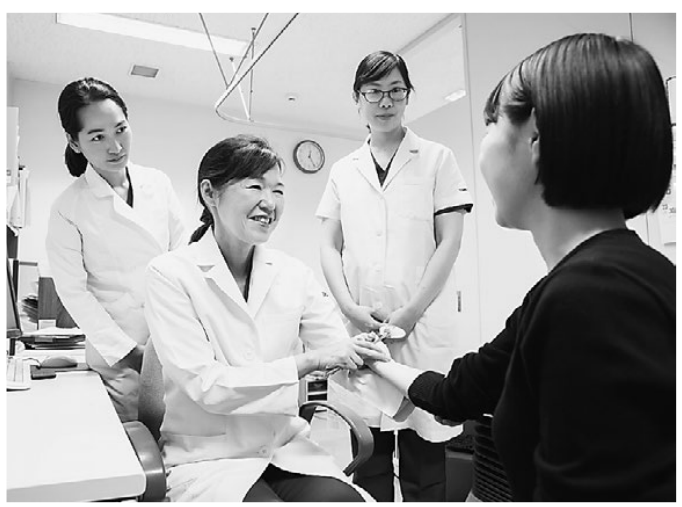

実際の診察室での様子

に必要なリハビリテーション医療を提供することが できます」と多職種回診の有効性について説明し ます。

\section{ドクターカーは多い日で}

\section{1 日 6〜 7 回出動}

東京医科歯科大学医学部附属病院の 2018 年の 年間救急患者数は，外来受診患者が 8,147 人，そ のうち外来受診後入院した患者が 2,742 人, 救急 搬送患者が 6,676 人，ホットライン（電話受付）後 に受診した患者が 943 人，その他が 3,165 人であ り，年間 1 万人を超える救急患者を受け入れてい ます。ささらに，ドクターカーも年間 295 件 (2017 年 実績）出動しており，多い日で 6〜7 回出動するこ とがあります。

「多様化・複雑化する救急医療, 脳卒中治療な どを中心に，1 人でも多くの患者さんに，それぞれ が必要とするリハビリテーション医療を提供してい きたいと考えています．医師は 4 人と少人数です

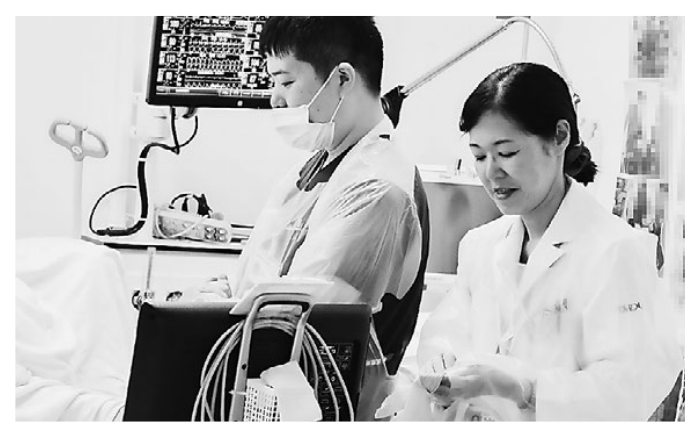

ICU で診療を行う酒井先生

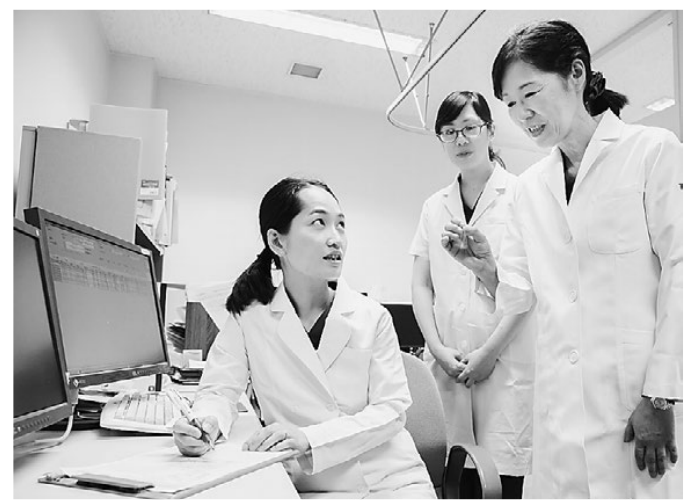

外来診療中に後輩医師にアドバイス

が, 幸いなことに優秀な理学療法士, 作業療法士, 言語聴覚士のスタッフが揃っており，日頃の診療 の中で経験を積みながら研鑽を続けてくれていま す」と先生. これにより手術後・発症後にできる限 り早期のリハビリテーション治療を開始することが できています，離床できない患者さんの場合には, 病室のベッドの上から積極的にリハビリテーション 治療を行っており, 不動による二次的な障害を予 防しながら患者さんの機能回復のサポートが実現 できているそうです.

歯学部附属病院とのコラボで肺炎防止 最後に先生は, 「同じ敷地内に, 歯学部附属病院 もあることで, 当院の入院患者さんに対する歯科 医師などによる誤嚥性肺炎予防のための口腔ケア や，口腔機能の適正な評価とそれに基づいたリハ ビリテーション治療が必要に応じて行われている ことも, 当院の大きなメリットです」と話してくれ ました。

（文責：広報委員会） 